\title{
The Effects of Swimming Training Program on Serum Minerals and Oxidative Stress in Men Aged 20-25 Years
}

\author{
Serdar Adıgüzel \\ School of Physical Education and Sports \\ Siirt University, Siirt, Turkey \\ E-mail: serdaradiguzel@siirt.edu.tr \\ Yeliz Doğru (Corresponding author) \\ Department of Health, Culture and Sports \\ İzmir Katip Çelebi University, İzmir, Turkey \\ E-mail: yeliz.dogru@hotmail.com
}

Received: September 22, 2021

Accepted: October 24, 2021

Published: November 11, 2021

doi:10.5296/jei.v7i2.19032

URL: https://doi.org/10.5296/jei.v7i2.19032

\begin{abstract}
In this study, the effects of 8-week swimming training applied to men aged 20-25 on sodium, potassium, magnesium, calcium, unsaturated iron binding capacity (UIBC), iron, CRP, creatinine, bilirubin, albumin parameters were investigated. Ten men with a mean age of $23.07 \pm 1.76$ years participated in the study. A swimming training program was applied to the participants for 10 weeks/3 days. All tests and measurements were performed before starting the 8 -week training program and after completing the 8-week program. The data obtained from the study were analyzed using the SPSS 15.0 package program. The normality distribution of the data was made using the shapiro-wilk test. Participants' pre-post test measurements were analyzed with the Wilcoxon signed-rank test. According to the results of the data, there was a statistically significant difference between pre-post test data for body weight (BW), sodium, magnesium, creatinine, albumin and bilirubin $(\mathrm{p}<0.05)$. As a result, it can be said that the changes in the minerals and some biochemical parameters necessary for the body with the training programs applied regularly can affect the performance.
\end{abstract}

Keywords: Sodium, CRP, Mineral, Albumin, Bilirubin 


\section{Introduction}

Tem Minerals determined as essential nutrients; sodium, potassium, magnesium, calcium and iron have biochemical functions that have the potential to affect physical performance (Trumbo et al., 2001). Calcium, magnesium, and iron serve various functions in the body, such as bone mineralization, serving as cofactors for many enzyme systems, maintaining muscle-nerve stimulation, and maintaining oxygen transport (Clarkson, 1991). Sufficient calcium intake is important in obtaining and maintaining the peak bone mass value (Dinç \& Eryavuz, 2002). Normal blood calcium level is 8.8-10.8 mg/dl. An adult human body contains about $1200 \mathrm{~g}$ of calcium. The importance of iron in the organism is indisputable. Iron deficiencies may occur as a result of imbalances in absorption or excretion (Koçyiğit et al., 2011). Iron loss in adults is irregular, and total iron stores in the body are controlled by the rate at which iron is absorbed from the small intestine. Men lose $0.6 \mathrm{mg}$ of iron per day and women about twice as much (Arslan et al., 2004). Although micronutrients such as magnesium are taken in very small amounts, unlike macronutrients, they play an important role in the regulation of whole body metabolism, including energy use and work performance (Lukaski, 2000). The recommended amount for daily athletes is $400 \mathrm{mg}$. Some studies have shown a sustained decrease in plasma magnesium levels after strenuous exercise (Monteiro et al., 1996; Resine et al., 1994). Potassium is taken up to 50-150 mmol daily in an average diet. The plasma potassium level remains within narrow limits of 3.5-5.0 mmol/L. Its stimulating effect, especially on nerves and muscles, makes potassium one of the most vital electrolytes. Potassium is the most important cation of the intracellular environment (Aygencel, 2018).

Serum CRP concentration is one of the parameters used in cardiovascular disease risk assessment, and its increase indicates proinflammation. CRP increased during circulation may be a response of the liver to increased proinflammatory cytokines during circulation, and many factors are responsible for high CRP levels (Esin et al., 2020). A compound called creatine is produced in the muscles, and the product formed as a result of the breakdown of this compound is called creatinine. Since creatinine levels vary according to muscle levels, creatinine levels in women are lower than in men. The reference range for creatinine can be between $0.6-1.2 \mathrm{mg} / \mathrm{dL}$ in men and $0.5-1.1 \mathrm{mg} / \mathrm{dL}$ in women. When people exercise intensely, working muscles build up creatinine much faster than normal levels. Thus, the creatinine levels in the blood also increase.

Swimming workouts of different duration and intensities activate different energy sources. At high intensity short distances, energy is obtained anaerobically, while at low intensity long distances, most of the energy is obtained aerobically using oxygen. In addition, the biochemical changes (increase/decrease) that may occur in the metabolism with the applied training are important in terms of sportive performance. Based on this information, the effect of applied swimming training on serum mineral and oxidative stress parameters was investigated.

\section{Method}

Male athletes $(\mathrm{N}=10)$ with $23.07 \pm 1.76$ specialties studying at Siirt University Physical Education and Sports School's coaching education department participated in the study. The 
training was carried out under the supervision of expert trainers. After the participants were informed about the study, they signed a "voluntary consent form" declaring that they voluntarily participated in the study. The physical activity levels of the volunteers were evaluated by completing the "International Physical Activity Questionnaire (IPAQ)" (Maddison et al., 2007), and those with a metabolic equivalent (MET) $<600$ were included in the study.

\subsection{Training Protocol}

Swimming training was applied to the participants for 2 hours a week for 8 weeks $/ 3$ days. The exercises started with 20 minutes of warm-up exercises. Warm-up exercises consist of 10 minutes of warm-up run, 10 minutes of mobility and flexibility exercises. The main working phase of the training lasted 60-80 minutes. Finished with 20 minutes of cool down (Table 1).

Table 1. Swimming training program

\begin{tabular}{|c|c|}
\hline Training Days & Program \\
\hline \multirow{3}{*}{ Monday } & $\begin{array}{l}\text { Dynamic Warm-up } \\
6 \text { moves } 15 \text { reps with thera-band for } 5 \text { minutes }\end{array}$ \\
\hline & $\begin{array}{l}\frac{\text { Major Phase }}{6 \times 100 \mathrm{~m} \text { free max swimming interval } 1 \mathrm{~min}} \\
6 \times 100 \mathrm{~m} \text { back max swimming interval } 1 \mathrm{~min}, \\
6 \times 100 \mathrm{~m} \text { breaststroke, max swimming break } 1 \mathrm{~min} \\
6 \times 100 \mathrm{~m} \text { butterfly swimming interval } 1 \mathrm{~min}\end{array}$ \\
\hline & $\begin{array}{l}\frac{\text { Cooling down }}{200 \mathrm{~m} \text { Breaststroke slow swim \& 25m Back deep arm slow swim }} \\
\end{array}$ \\
\hline \multirow{3}{*}{ Wednesday } & $\begin{array}{l}\text { Dynamic Warm-up } \\
6 \text { moves } 15 \text { reps with thera-band for } 5 \text { minutes }\end{array}$ \\
\hline & $\begin{array}{l}\frac{\text { Major Phase }}{1 \times 2000 \mathrm{~m} \text { freestyle technique } 3 \text { min break after } 1000 \mathrm{~m}} \\
4 \times 50 \mathrm{~m} 1 \mathrm{~min} \times \text { butterfly max swimming, } 1 \mathrm{~min} \times \text { back technical swimming } 15 \mathrm{~min} \\
4 \times 100 \mathrm{~m} \text { breaststroke technique slow swimming } 100 \mathrm{~m} .30 \mathrm{sec} \text { rest between }\end{array}$ \\
\hline & $\begin{array}{l}\frac{\text { Cooling down }}{200 \mathrm{~m} 25 \mathrm{~m} \text { breaststroke slow } \& 25 \mathrm{~m} \text { back slow }} \\
\end{array}$ \\
\hline \multirow{3}{*}{ Friday } & $\begin{array}{l}\frac{\text { Dynamic Warm-up }}{6 \text { moves } 15 \text { reps with thera-band for } 5 \text { minutes }} \\
\text {. }\end{array}$ \\
\hline & $\begin{array}{l}\text { Major Phase } \\
1 \text { minute rest between } 8 \times 25 \mathrm{~m} \text { sets } \\
2 \text { min rest between } 8 \times 50 \mathrm{~m} \text { free sets } \\
3 \text { minutes rest between } 4 \times 100 \mathrm{~m} \text { free sets }\end{array}$ \\
\hline & $\frac{\text { Cooling down }}{200 \mathrm{~m} 25 \mathrm{~m} \text { breaststroke slow \& } 25 \mathrm{~m} \text { back slow }}$ \\
\hline
\end{tabular}




\subsection{Anthropometric Measurements}

In our study, height measurement was measured with a Seca 769 (Hamburg, Germany) brand device while the athlete was barefoot on a flat surface. Body weight was measured with a Tanita (Innerscan BC532/Japan) device.

\subsection{Blood Measurement}

Biochemical analyzes were performed with venous blood samples $(9 \mathrm{ml})$ taken by experts at the Siirt Training and Research Hospital Public Health Laboratory between 08:00 and 10:00 in the morning after 12 hours of fasting. In the samples taken; sodium, potassium, magnesium, calcium, UIBC, iron, CRP, creatinine, bilirubin, albumin tests were studied. The serum and plasma samples separated by centrifugation were stored at $-80{ }^{\circ} \mathrm{C}$ and studied collectively (within 2 months). Measurements were made 8 weeks before and after 48 hours of complete rest.

\subsection{Statistical Analysis}

The data obtained from the study were analyzed using the SPSS 15.0 package program. The normality distribution of the data was made using the shapiro-wilk test. Participants' pre-post test measurements were analyzed with the Wilcoxon signed-rank test. All parameters of the participants were shown as minimum, maximum, mean and standard deviation. The significance value was accepted as $\mathrm{p}<0.05$.

\section{Results}

The descriptive parameters of the participants are shown in Table 2.

Table 2. Descriptive parameters of participants

\begin{tabular}{|l|l|l|l|}
\hline Parameters & Minimum & Maximum & Mean \pm SD \\
\hline Age (years) & 20.00 & 25.00 & $23.7 \pm 1.76$ \\
\hline Height $(\mathrm{cm})$ & 169.00 & 188.00 & $177.9 \pm 5.42$ \\
\hline Body weight $(\mathrm{kg})$ & 54.40 & 84.80 & $72.72 \pm 10.66$ \\
\hline
\end{tabular}

The comparison of the pre-test and post-test values of the 8-week swimming training program is shown in Table 3. According to this; There was a statistically significant difference between pre-post test data for BW, sodium, magnesium, creatinine, albumin and bilirubin $(\mathrm{p}<0.05)$. 
Table 3. Comparison of participants' pre- and post-test values

\begin{tabular}{|l|l|l|l|l|l|}
\hline \multirow{2}{*}{ Parameters } & \multicolumn{2}{|c|}{ Pre Test } & \multicolumn{2}{c|}{ Post Test } & \multirow{2}{*}{ P } \\
\cline { 2 - 6 } & Min-Max. & Mean \pm SD & Min-Max. & Mean \pm SD & \\
\hline BW (kg) & $54.40-84.80$ & $72.72 \pm 10.66$ & $53.40-80.0$ & $69.88 \pm 9.91$ & $.005^{*}$ \\
\hline Sodium (mEq/L) & $140-145$ & $141.9 \pm 1.59$ & $137-140$ & $138.3 \pm 1.15$ & $.007^{*}$ \\
\hline Potassium (mEq/L) & $4-4.80$ & $4.30 \pm .25$ & $3.60-4.70$ & $4.21 \pm .34$ & .461 \\
\hline Magnesium (mg/dl) & $1.79-2.27$ & $2.02 \pm .14$ & $1.79-2.44$ & $2.15 \pm .16$ & $.033^{*}$ \\
\hline Calcium (mg/dl) & $9.73-10.22$ & $9.93 \pm .16$ & $9.50-10.40$ & $9.87 \pm .24$ & .286 \\
\hline UIBC (ug/dl) & $161-382$ & $224.3 \pm 62.16$ & $116.30-318.90$ & $237.64 \pm 70.23$ & .515 \\
\hline Iron (ug/dl) & $2.90-118$ & $66.39 \pm 38.49$ & $2.90-175$ & $87.29 \pm 55.98$ & .214 \\
\hline CRP (mg/L) & $1.50-4.30$ & $2.33 \pm .93$ & $.90-4.30$ & $1.60 \pm 1.25$ & .086 \\
\hline Creatinine (mg/dl) & $.78-1.08$ & $.91 \pm .09$ & $.87-1.22$ & $1.04 \pm .10$ & $.008^{*}$ \\
\hline Bilirubin (mg/dl) & $.40-1.20$ & $.62 \pm .25$ & $.30-1.54$ & $.83 \pm .41$ & $.021^{*}$ \\
\hline Albumin (g/l) & $47-54$ & $49.5 \pm 2.01$ & $41.93-50.58$ & $46.01 \pm 2.44$ & $.008^{*}$ \\
\hline
\end{tabular}

Note. $\mathrm{p}<0.05$.

\section{Discussion and Conclusion}

In this study, the effects of swimming training applied to men aged 20-25 on serum minerals and oxidative stress were investigated. Akın et al. (2011) examined the effects of a 12-week aerobic exercise program on serum mineral levels of sedentary young women. While a significant increase in calcium values and a significant decrease in iron and sodium values were reported $(\mathrm{p}<0.01)$, no significant difference was reported in potassium and magnesium values $(p>0.05)$. In our study, a decrease in sodium values was also detected. Studies have drawn attention to the decrease in sodium levels after exercise. Yücer (2019) examined the effect of an 8-week training program on mineral levels in 11-12 age group swimmers. As a result; It was reported that there was no statistically significant difference in sodium, calcium, potassium, magnesium and iron values $(\mathrm{p}>0.05)$. Although not statistically, it has been reported that the sodium value decreases and the replacement of minerals with diet is important for both healthy life and performance in sports. Döker et al. (2004); investigated the effect of swimming frequency on serum concentrations of some trace elements (chromium, iron, copper, zinc, selenium) and electrolytes (sodium, magnesium, potassium, calcium) in elite, amateur swimmers and sedentary swimmers. Blood samples taken before, immediately after and 1 hour after the 3-week training program applied to elite and amateur swimmers were examined. It was determined that elite swimmers had higher pre-test calcium and potassium levels than other groups. The researchers emphasized that the results were 
related to the adaptive mechanisms revealed by frequent training and the importance of regular control of the baseline. Saraymen et al. (2003) evaluated the loss of iron and magnesium in sweat in their study on boxers. Sweat samples were collected at $50 \%$ VO2 peak for 30 minutes while the boxers trained at room temperature. As a result, it has been reported that significant amounts of trace elements are excreted from the sweat of boxers during training. It has been reported that magnesium and iron supplementation may be important for athletes to achieve maximum performance. Meludu et al. (2002) investigated the effects of anaerobic exercise on serum mineral concentration after a day of inactivity. Anaerobic exercise has been reported to cause a significant increase in calcium and potassium levels. After 12 hours, the magnesium level remained high, while the potassium and calcium levels returned to normal. It clearly shows that mineral levels change more after anaerobic exercise compared to the day without activity. Kara (2012) investigated the effects of a 24-week exercise program on calcium, sodium, potassium, iron and magnesium parameters in young men. As a result, it was reported that while significant changes were detected in calcium, potassium and sodium parameters, they did not change magnesium and iron levels. In our study, a decrease in sodium levels and an increase in magnesium were detected. It can be suggested that people who exercise regularly should pay attention to their nutrition, as they may experience health problems due to trace element deficiency if they do not pay attention to their nutrition.

Campbell et al. (2009) had sedentary women do aerobic exercise for 45 minutes a day, 5 days a week for 1 year. At the end of one year, CRP levels decreased by $10 \%$ in the exercising group and increased by $12 \%$ in the control group. In another study (Stewart et al., 2010), postmenopausal women were divided into three different aerobic exercise groups. After six months of the program, CRP levels were found to be similar in all groups. As a result, while CRP levels decrease with rapid response to exercise, there are studies in which the exercise program is not effective. It can be said that the presence of factors such as individual differences, body weight, obesity, and CRP levels affect the response to exercise. Albumin is a protein that makes up the majority of plasma proteins and acts at stable reference values (Çetinkaya \& Çelik, 2020). While a decrease in albumin values was detected as a result of a study conducted with bicycle simulation (Voss et al., 2014), an increase in albumin values was reported in an exercise study in which water consumption was prohibited (Miller et al., 2019). In our study, significant increases occurred in bilirubin, albumin and creatinine. In summary, it should not be forgotten that while exercising regularly, attention should be paid to nutritional intake, mineral deficiency may occur in cases where attention is not paid, and performance will deteriorate in cases of mineral deficiency.

\section{References}

Akça, E., Aydın, M. S., Padak, M., Göz, M., Dikme, R., \& Göç, Ö. (2020). Normotermik Kardiyopulmoner Bypass Sırasında Enflamasyon Parametrelerindeki Değişiklikler İle Oksidatif Stresin Değerlendirilmesi. Dicle Tip Dergisi, 47(1), 223-231. https://doi.org/ 10.5798/dicletip.706148

Akı1, M., Kara, E., \& Yalçınkaya, Ö. (2011). 12 haftalık aerobik egzersiz programının genç 
bayanların serum mineral düzeylerine etkisi. Atatürk Üniversitesi Beden Ĕgitimi ve Spor Bilimleri Dergisi, 13(3), 21-26.

Arslan, C., Gönül, B., Dinçer, S., Kaplan, B., \& Çevik, C. (2004). Güreşçilerde C vitamini yüklemesinin serum demir ve total demir bağlama kapasitesine etkisi. Fırat Üniversitesi Sağlık Bilimleri Tıp Dergisi, 18(2), 215-21.

Aygencel, G. (2018). Potasyum metabolizması bozuklukları. Yoğun Bakım Dergisi, 12(1), $31-42$.

Campbell, P. T., Campbell., K. L, Wener, M. H., Wood, B. L., Potter, J. D., McTiernan, A., \& Ulrich, C. M. (2009). A year long exercise intervention decreases CRP among obese postmenopausal women. Medicine \& Science in Sports \& Exercise, 41(8), 1533-9. https://doi.org/10.1249/MSS.0b013e31819c7feb

Çetinkaya, A., \& Çelik, H. (2020). Egzersizin Plazma Proteinleri Üzerine Etkisi. Research in Health Sciences, 341.

Clarkson, P. M. (1991). Minerals: Exercise performance and supplementation in athletes. Journal of Sports Sciences, 9(S1), 91-116. https://doi.org/10.1080/02640419108729869

Dinç, A., \& Eryavuz, M. (2002). Osteoporosis and dietary factors. Turk J Osteoporos, 8, 89-93.

Döker, S., Hazar, M., Uslu, M., Okan, İ., Kafkas, E., \& Boşgelmez, İ. İ. (2014). Influence of training frequency on serum concentrations of some essential trace elements and electrolytes in male swimmers. Biological Trace Element Research, 158(1), 15-21. https://doi.org/ 10.1007/s12011-014-9912-z

Kara, E., \& Ak1l, M. (2012). The effect of aerobic exercise programme on trace element levels of young men. African Journal of Microbiology Research, 6(1), 165-168. https://doi.org/10.5897/AJMR11.1169

Koçyiğit, Y., Aksak, M. C., Atamer, Y., Aktaş, A., \& Uysal, E. (2011). Antrene sporcularda C vitamini yüklemesinin demir ve demir bağlama kapasitesi üzerine etkileri. Journal of Clinical and Experimental Investigations, 2(2).

Lukaski, H. C. (2000). Magnesium, zinc, and chromium nutriture and physical activity. The American Journal of Clinical Nutrition, 72(2), 585S-593S. https://doi.org/10.1093/ajcn/ $72.2 .585 \mathrm{~S}$

Maddison, R., Mhurchu, C. N., Jiang, Y., Vander Hoorn, S., Rodgers, A., Lawes, C. M., \& Rush, E. (2007). International physical activity questionnaire (IPAQ) and New Zealand physical activity questionnaire (NZPAQ): A doubly labelled water validation. International Journal of Behavioral Nutrition and Physical Activity, 4(1), 1-9. https://doi.org/10.1186/ 1479-5868-4-62

Meludu, S. C., Nishımuta, M., Yoshitake, Y., Toyooka, F., Kodoma, N., Kim, C. S., ... Fukuoka, H. (2002). Anaerobic Exercise-Induced Changes in Serum Mineral 
Concentrations. The African Journal of Biomedical Research, 5, 13-17.

Miller, G. D., Teramoto, M., Smeal, S. J., Cushman, D., \& Eichner, D. (2019). Assessing serum albumin concentration following exercise-induced fluid shifts in the context of the athlete biological passport. Drug Test Anal, 11(6), 782-791. https://doi.org/10.1002/dta.2571

Monteiro, C. P., Palmeira, A., Sarmento, G., Vaz, C. A., Rodrigues, A., Barata, J., \& Laires, M. J. (1996). Magnesium, Calcium, Trace Elements and Lipid Profile in Trained Volleyball Players: Influence of Training. In M. J. Halpern \& J. Durlach (Eds.), Current Research in Magnesium (pp. 231-5). London: John Libbey \& Company Ltd.

Resina, A., Brettoni, M., Gatteschi, L., Galvan, P., Orsi, F., \& Rubenni, M. G. (1994). Changes in the concentrations of plasma and erythrocyte magnesium and of 2,3-diphosphoglycerate during a period of aerobic training. European Journal of Applied Physiology and Occupational Physiology, 68, 390-4. https://doi.org/10.1007/BF00843734

Saraymen, R., Kilic, E., Yazar, S., \& Saraymen, B. (2003). Magnesium, copper, zinc, iron and chromium levels in sweat of boxers. Inönü Üniversitesi Tip Fakültesi Dergisi, 10(3), 121-125.

Stewart, L. K., Earnest, C. P., Blair, S. N., \& Church, T. S. (2010). Effects of different doses of physical activity on C-reactive protein among women. Medicine \& Science in Sports \& Exercise, 42(4), 701-7. https://doi.org/10.1249/MSS.0b013e3181c03a2b

Trumbo, P., Yates, A. A., Schlicker, S., \& Poos, M. (2001). Dietary reference intakes: vitamin A, vitamin $\mathrm{K}$, arsenic, boron, chromium, copper, iodine, iron, manganese, molybdenum, nickel, silicon, vanadium, and zinc. Journal of the American Dietetic Association, 101(3), 294-301. https://doi.org/10.1016/S0002-8223(01)00078-5

Voss, S. C., Alsayrafi, M., Bourdon, P. C., Klodt, F., Nonis, D., Hopkins, W. G., \& Schumacher, Y. O. (2014). Variability of serum markers of erythropoiesis during 6 days of racing in highly trained cyclists. International Journal of Sports Medicine, 35(2), 89-94. https://doi.org/10.1055/s-0033-1345177

\section{Copyright Disclaimer}

Copyright for this article is retained by the author(s), with first publication rights granted to the journal.

This is an open-access article distributed under the terms and conditions of the Creative Commons Attribution license (http://creativecommons.org/licenses/by/3.0/). 